\title{
Influence of interleukin-18 gene polymorphisms on acute pancreatitis susceptibility in a Chinese population
}

\author{
H.B. Gui ${ }^{1}$, X.G. Du' ${ }^{2}$ Z.H. Fu ${ }^{3}$ and X.M. Chen ${ }^{1}$ \\ ${ }^{1}$ Department of Emergency, \\ The First Affiliated Hospital of Chongqing Medical University, Chongqing, China \\ ${ }^{2}$ Department of Nephrology, \\ The First Affiliated Hospital of Chongqing Medical University, Chongqing, China \\ ${ }^{3}$ Department of Prosthodontics, The Affiliated Hospital of Stomatology, \\ Chongqing Medical University, Chongqing, China \\ Corresponding author: X.M. Chen \\ E-mail: chenxmm66@163.com
}

Genet. Mol. Res. 15 (3): gmr.15038394

Received January 7, 2016

Accepted February 26, 2016

Published August 26, 2016

DOI http://dx.doi.org/10.4238/gmr.15038394

Copyright (C) 2016 The Authors. This is an open-access article distributed under the terms of the Creative Commons Attribution ShareAlike (CC BY-SA) 4.0 License.

ABSTRACT. We investigate the relationship between $I L-18-607 \mathrm{C} /$
$\mathrm{A}$ and $-137 \mathrm{G} / \mathrm{C}$ genetic polymorphisms and development of acute
pancreatitis in a Chinese population. A total of 153 patients were
consecutively recruited from the First Affiliated Hospital of Chongqing
Medical University between January 2013 and November 2014 .
Genotyping of $I L-18-607 \mathrm{C} / \mathrm{A}$ and $-137 \mathrm{G} / \mathrm{C}$ variants was performed
using the polymerase chain reaction-restriction fragment length
polymorphism method. We observed a significant difference between
acute pancreatitis patients and control subjects with respect to age $(t=$
$2.15, \mathrm{P}=0.02)$, gender (chi-square $=3.95, \mathrm{P}=0.04)$, body mass index
$(t=5.85, \mathrm{P}<0.001)$, and alcohol consumption (chi-square $=9.74, \mathrm{P}=$ 
0.002). Using chi-square tests, we found that the genotype distributions of $I L-18-607 \mathrm{C} / \mathrm{A}$ (chi-square $=0.81, \mathrm{P}=0.67$ ) and $-137 \mathrm{G} / \mathrm{C}$ (chisquare $=1.16, \mathrm{P}=0.56$ ) polymorphisms did not differ between the acute pancreatitis and control groups. Genotype frequencies of these variants were consistent with Hardy-Weinberg equilibrium in both patient and control groups. In addition, logistic regression analysis failed to identify a significant association between these polymorphisms and acute pancreatitis risk. Our study firstly examined their association in a Chinese population, and we suggest that the $I L-18-607 \mathrm{C} / \mathrm{A}$ and $-137 \mathrm{G} /$ $\mathrm{C}$ polymorphisms do not influence susceptibility to acute pancreatitis in the Chinese population studied in the present study.

Key words: $I L-18$; Polymorphism; Acute pancreatitis; Chinese population

\section{INTRODUCTION}

Acute inflammation of the pancreas, known as acute pancreatitis, has an estimated mortality rate between 10 and 25\%, based on the condition of this disease (Yousaf et al., 2003). The development of acute pancreatitis involves various environmental and lifestyle factors, such as gallstones, heavy alcohol consumption and obstructed pancreatic ducts (Kumaravel et al., 2014; Yuhara et al., 2014; Lankisch et al., 2015). Not all individuals subject to acute pancreatitis risk factors go on to develop this disease, which indicates that genetic influences may contribute to the development of this disease. Recently, many studies have suggested that interleukin (IL) genes, such as $I L-10, I L-1 \beta, I L-8$, and $I L-6$ play an important role in the development of acute pancreatitis (Bao et al., 2015b; Chi et al., 2015; Jia et al., 2015; Li et al., 2015a).

The $I L-18$ gene is located on chromosome 11q22.2-q22.3, and including includes six exons and five introns. Genetic polymorphisms capable of altering the function and efficiency of IL-18 may contribute to disease development risk. The single nucleotide polymorphism -607C/A (rs1946518) has been confirmed to have an impact on IL-18 tissue activity and expression (Kalina et al., 2000; Giedraitis et al., 2001). Therefore, we conducted a casecontrol study to investigate the association between the $I L-18-607 \mathrm{C} / \mathrm{A}$ and $-137 \mathrm{G} / \mathrm{C}$ genetic polymorphisms and development of acute pancreatitis in a Chinese population.

\section{MATERIAL AND METHODS}

\section{Subjects}

A total of 153 acute pancreatitis patients were consecutively recruited from the First Affiliated Hospital of Chongqing Medical University between January 2013 and November 2014. The acute pancreatitis was diagnosed based on a computerized tomography (CT) scan and clinical manifestation. The exclusion criteria were individuals with a history of cancers, serious infectious diseases, malnutrition, endocrine disease, or serious liver or kidney diseases.

A total of 182 healthy controls were recruited, consisting of individuals having received a regular physical examination at our hospital during the same period. All controls confirmed the absence of acute pancreatitis, digestive diseases, or endocrine disease.

Genetics and Molecular Research 15 (3): gmr.15038394 
Data concerning demographic and lifestyle factors of acute pancreatitis patients and control subjects were collected from medical records or a self-designed questionnaire, and included age, gender, family history of acute pancreatitis, body mass index (BMI), and tobacco and alcohol consumption. The subjects provided their informed consent before participating in our investigation. This study was approved by the Ethics Committee of the First Affiliated Hospital of Chongqing Medical University.

\section{Genotyping analysis}

Five peripheral blood samples, collected in vacuum tubes containing 5\% ethylenediaminetetraacetic acid, were taken from each study subject. Genomic DNA was extracted using a QIAGEN DNA Blood Mini Kit (QIAGEN, Valencia, CA, USA), following the manufacturer protocol. Genotyping of the $I L-18-607 \mathrm{C} / \mathrm{A}$ and $-137 \mathrm{G} / \mathrm{C}$ polymorphisms was performed using the polymerase chain reaction (PCR)-restriction fragment length polymorphism technique. DNA samples were amplified using two different primer pairs specific for these two polymorphic regions of the $I L-18$ gene. The primer sequences and PCR products are shown in Table 1. The restriction enzymes for $I L-18-607 \mathrm{C} / \mathrm{A}$ and $-137 \mathrm{G} / \mathrm{C}$ were $M s e I$ and $B f u C I$, respectively. The PCR products for $I L-18-607 \mathrm{C} / \mathrm{A}$ and $-137 \mathrm{G} / \mathrm{C}$ were 196 and $261 \mathrm{bp}$, respectively. The cycling conditions were as follows: $94^{\circ} \mathrm{C}$ for $5 \mathrm{~min}$, followed by 35 cycles of $94^{\circ} \mathrm{C}$ for $30 \mathrm{~s}, 61^{\circ} \mathrm{C}$ for $45 \mathrm{~s}$, and $72^{\circ} \mathrm{C}$ for $50 \mathrm{~s}$, before a final elongation at $72^{\circ} \mathrm{C}$ for $5 \mathrm{~min}$.

\begin{tabular}{|c|c|c|}
\hline Polymorphism & Primer sequences & PCR product (bp) \\
\hline$-607 \mathrm{C} / \mathrm{A}$ & $\begin{array}{l}\text { 5'-CCCTCTCCCCAAGCTTACTT-3' } \\
\text { 5'-TTGAGTGGAACAGGAGTCGA-3' }\end{array}$ & 196 \\
\hline$-137 \mathrm{G} / \mathrm{C}$ & $\begin{array}{l}\text { 5'-TTGTAACATTGTAGGAATTACC-3' } \\
\text { 5'-ATGTAATATCAGTATTTTGATGAGA-3' }\end{array}$ & 261 \\
\hline
\end{tabular}

\section{Statistical analysis}

Chi-square and Student $t$-tests were taken to analyze the categorical and continuous variables. The Pearson chi-square test was used to analyze statistical differences in $I L-18-607 \mathrm{C} /$ $\mathrm{A}$ and $-137 \mathrm{G} / \mathrm{C}$ allele and genotype frequencies between acute pancreatitis patients and control subjects. Departure of $I L-18-607 \mathrm{C} / \mathrm{A}$ and $-137 \mathrm{G} / \mathrm{C}$ genotype frequencies from Hardy-Weinberg equilibrium (HWE) was evaluated using chi-square tests. To test the relationship between the $I L-18$ polymorphisms of interest and risk of acute pancreatitis, logistic regression analysis was employed to calculate adjusted odds ratios and 95\% confidence intervals. SPSS 20.0 (SPSS Inc., Chicago, IL, USA) was used for all data analysis. P values $<0.05$ were considered statistically significant.

\section{RESULTS}

The demographic and lifestyle characteristics of the study subjects are shown in Table 2. Using chi-square or Student $t$-tests, we observed that patients were comparable to controls in terms of family history of acute pancreatitis (chi-square $=1.09, \mathrm{P}=0.29$ ) and tobacco smoking (chi-square $=0.83, \mathrm{P}=0.36$ ). However, we found a significant difference between

Genetics and Molecular Research 15 (3): gmr.15038394 
H.B. Gui et al.

these two groups with respect to age $(t=2.15, \mathrm{P}=0.02)$, gender (chi-square $=3.95, \mathrm{P}=0.04)$, BMI $(t=5.85, \mathrm{P}<0.001)$, and alcohol consumption (chi-square $=9.74, \mathrm{P}=0.002)$.

\begin{tabular}{|c|c|c|c|c|c|c|}
\hline Variable & Patients ( $\mathrm{N}=153)$ & $\%$ & Controls $(\mathrm{N}=182)$ & $\%$ & Chi-square or $t$-test & $P$ value \\
\hline Age, years & \multicolumn{2}{|l|}{$65.86 \pm 8.50$} & \multicolumn{2}{|l|}{$63.73 \pm 9.42$} & 2.15 & 0.02 \\
\hline \multicolumn{7}{|l|}{ Gender } \\
\hline Female & 55 & 35.95 & 85 & 46.70 & & \\
\hline Male & 98 & 64.05 & 97 & 53.30 & 3.95 & 0.04 \\
\hline \multicolumn{7}{|c|}{ Family history of acute pancreatitis } \\
\hline No & 149 & 97.39 & 180 & 98.90 & & \\
\hline Yes & 4 & 2.61 & 2 & 1.10 & 1.09 & 0.29 \\
\hline$\overline{\text { BMI, } \mathrm{kg} / \mathrm{m}^{2}}$ & \multicolumn{2}{|l|}{$25.36 \pm 3.58$} & \multicolumn{2}{|l|}{$23.17 \pm 3.27$} & 5.85 & $<0.001$ \\
\hline \multicolumn{7}{|c|}{ Tobacco smoking } \\
\hline No & 97 & 63.40 & 124 & 81.05 & & \\
\hline Yes & 56 & 36.60 & 58 & 37.91 & 0.83 & 0.36 \\
\hline \multicolumn{7}{|c|}{ Alcohol consumption } \\
\hline No & 86 & 56.21 & 132 & 86.27 & & \\
\hline Yes & 67 & 43.79 & 50 & 32.68 & 9.74 & 0.002 \\
\hline
\end{tabular}

$\mathrm{BMI}=$ body mass index.

The distributions of $I L-18-607 \mathrm{C} / \mathrm{A}$ and $-137 \mathrm{G} / \mathrm{C}$ genotypes are presented in Table 3 . Among patients, 96 (62.75\%), 45 (29.41\%), and 12 (7.84\%) individuals carried the CC, CA, and AA genotypes of $I L-18-607 \mathrm{C} / \mathrm{A}$, respectively, while $40(26.14 \%), 74(48.37 \%)$, and 39 $(25.49 \%$ ) were found to have the GG, GC, and CC genotypes of $I L-18-137 \mathrm{G} / \mathrm{C}$, respectively. In the control group, $122(67.03 \%), 49(26.92 \%)$, and $11(6.04 \%)$ subjects were observed to have the CC, CA, and AA genotypes of $I L-18-607 \mathrm{C} / \mathrm{A}$, respectively, while $57(31.32 \%), 82(45.05 \%)$, and $42(23.63 \%)$ carried the GG, GC, and CC genotypes of $I L-18-137 \mathrm{G} / \mathrm{C}$, respectively. Chisquare tests failed to reveal significant differences in the genotype distributions of the $-607 \mathrm{C} / \mathrm{A}$ (chi-square $=0.81, \mathrm{P}=0.67$ ) and $-137 \mathrm{G} / \mathrm{C}($ chi-square $=1.16, \mathrm{P}=0.56)$ polymorphisms between the study groups. The genotype frequencies of these variants did not depart from HWE in either the patient or the control group. Using logistic regression analysis, we found no significant association between the $I L-18-607 \mathrm{C} / \mathrm{A}$ and $-137 \mathrm{G} / \mathrm{C}$ polymorphisms and acute pancreatitis risk.

Table 3. Relationship between $I L-18-607 \mathrm{C} / \mathrm{A}$ and $-137 \mathrm{G} / \mathrm{C}$ polymorphisms and acute pancreatitis risk.

\begin{tabular}{|c|c|c|c|c|c|c|c|c|c|c|}
\hline \multirow[t]{2}{*}{$I L-18$} & \multirow[t]{2}{*}{ Patients $(\mathrm{N}=153)$} & \multirow[t]{2}{*}{$\%$} & \multirow[t]{2}{*}{ Controls $(\mathrm{N}=182)$} & \multirow[t]{2}{*}{$\%$} & \multirow[t]{2}{*}{ Chi-square } & \multirow[t]{2}{*}{$\mathrm{P}$} & \multicolumn{2}{|c|}{$\mathrm{P}$ for HWE } & \multirow[t]{2}{*}{ OR $(95 \% \mathrm{CI})^{1}$} & \multirow[t]{2}{*}{$\mathrm{P}$} \\
\hline & & & & & & & $\begin{array}{c}\text { Patient } \\
\text { s }\end{array}$ & Controls & & \\
\hline \multicolumn{11}{|c|}{$-607 \mathrm{C} / \mathrm{A}$} \\
\hline $\mathrm{CC}$ & 96 & 62.75 & 122 & 67.03 & & & & & 1.0 (Ref.) & \\
\hline $\mathrm{CA}$ & 45 & 29.41 & 49 & 26.92 & & & & & $1.17(0.70-1.95)$ & 0.53 \\
\hline$\overline{\mathrm{AA}}$ & 12 & 7.84 & 11 & 6.04 & 0.81 & 0.67 & 0.06 & 0.06 & $1.39(0.53-3.63)$ & 0.46 \\
\hline \multicolumn{11}{|l|}{ Allele } \\
\hline $\mathrm{C}$ & 237 & 77.45 & 293 & 80.49 & & & & & 1.0 (Ref.) & \\
\hline $\bar{A}$ & 69 & 22.55 & 71 & 19.51 & 0.93 & 0.33 & & & $1.20(0.81-1.78)$ & 0.33 \\
\hline \multicolumn{11}{|c|}{$-137 \mathrm{G} / \mathrm{C}$} \\
\hline GG & 40 & 26.14 & 57 & 31.32 & & & & & 1.0 (Ref.) & \\
\hline$\overline{\mathrm{GC}}$ & 74 & 48.37 & 82 & 45.05 & & & & & $1.29(0.75-2.22)$ & 0.34 \\
\hline $\mathrm{CC}$ & 39 & 25.49 & 43 & 23.63 & 1.16 & 0.56 & 0.69 & 0.24 & $1.32(0.70-2.50)$ & 0.36 \\
\hline \multicolumn{11}{|l|}{ Allele } \\
\hline G & 154 & 50.33 & 196 & 53.85 & & & & & 1.0 (Ref.) & \\
\hline $\mathrm{C}$ & 152 & 49.67 & 168 & 46.15 & 0.97 & 0.33 & & & $1.17(0.85-1.60)$ & 0.33 \\
\hline
\end{tabular}

${ }^{1}$ Adjusted for age, gender, body mass index, and alcohol consumption. HWE $=$ Hardy-Weinberg equilibrium, OR = odds ratio, $\mathrm{CI}=$ confidence interval, Ref. $=$ reference.

Genetics and Molecular Research 15 (3): gmr.15038394 


\section{DISCUSSION}

In the present study, we evaluated the relationship between the $I L-18-607 \mathrm{C} / \mathrm{A}$ and $-137 \mathrm{G} / \mathrm{C}$ polymorphisms and acute pancreatitis risk in a Chinese population, finding that these sequence variations did not contribute to the development of this disease.

Previous studies have reported that $I L-18$ sequence variations are associated with several diseases, including tuberculosis, rheumatoid arthritis, Crohn's disease, Helicobacter pylori infection, ischemic stroke, hepatitis B virus (HBV)-related liver disease, hepatocellular carcinoma, and other cancers (Liu et al., 2013; Angelo et al., 2015; Bao et al., 2015a; Gao et al., 2015; Karra et al., 2015; Li et al., 2015b; Myung et al., 2015; Shi et al., 2015; Zhou et al., 2015). Zhou et al. (2015) examined the association between the polymorphisms under investigation in the present study and tuberculosis, reporting that the $-137 \mathrm{G} / \mathrm{C}$ variant contributes to susceptibility to this disease in the Han Chinese population. In a study of a Brazilian population, Angelo et al. (2015) suggested a possible role for $I L-18$ polymorphism in rheumatoid arthritis, while Gao et al. (2015) indicated that variants of this gene may contribute to susceptibility to Crohn's disease in Asians and Africans. Bao et al. (2015a) conducted an investigation involving 153 patients and 165 healthy controls from a Chinese population, finding that the $I L-18-137 \mathrm{G} / \mathrm{C}$ polymorphism may play a protective role in hepatocellular carcinoma. In addition, Myung et al. (2015) suggested that $I L-18$ may contribute to the pathogenesis of $H$. pylori-associated diseases. A meta-analysis of 29 studies performed by Li et al. (2015b) revealed the $I L-18$ $-607 \mathrm{C} / \mathrm{A}$ polymorphism to correlate with a significantly increased risk of breast cancer, nasopharyngeal carcinoma, and esophageal cancer. Moreover, Shi et al. (2015) conducted a study of 322 Chinese ischemic stroke patients and 322 controls, demonstrating that $I L-18$ $-607 \mathrm{C} / \mathrm{A}$ influences the development of this condition, while Karra et al. (2015) reported that this same polymorphism may confer protection against HBV infection in an Indian population. These studies indicate that $I L-18$ genetic polymorphisms may contribute to the development of various diseases.

Currently, only one study have examined the role of serum concentrations of $I L$ 18 in the prognosis of acute pancreatitis (Janiak et al., 2015). Janiak et al. (2015) carried out a study of 32 patients with acute pancreatitis, suggesting that IL-18 level increases in the initial phase of acute pancreatitis. However, no study have investigated the association between $I L-18$ polymorphism and development of acute pancreatitis. The exact molecular mechanisms underlying the pathogenesis of acute pancreatitis remain to be investigated in further studies.

Two limitations of the present study should be taken into account. First, selection bias may have been present, as all patients and control subjects were recruited from one hospital. Second, other genes that may influence the development of acute pancreatitis were not considered in our analysis.

In summary, no previous studies have examined the relationship between $I L$ 18 polymorphisms and acute pancreatitis risk until now. Our study firstly examined their association in a Chinese population, and we suggest that the $I L-18-607 \mathrm{C} / \mathrm{A}$ and $-137 \mathrm{G} / \mathrm{C}$ polymorphisms do not influence susceptibility to acute pancreatitis in the Chinese population studied in the present work. Further investigations with large sample size on the molecular mechanisms underlying the pathogenesis of acute pancreatitis are greatly requires.

Genetics and Molecular Research 15 (3): gmr.15038394 


\section{Conflicts of interest}

The authors declare no conflict of interest.

\section{REFERENCES}

Angelo HD, Gomes Silva II, Oliveira RD, Louzada-Júnior P, et al. (2015). Interleukin-18, interleukin-12B and interferon-g gene polymorphisms in Brazilian patients with rheumatoid arthritis: a pilot study. Tissue Antigens 86: 276-278. http://dx.doi.org/10.1111/tan.12645

Bao J, Lu Y, Deng Y, Rong C, et al. (2015a). Association between IL-18 polymorphisms, serum levels, and HBV-related hepatocellular carcinoma in a Chinese population: a retrospective case-control study. Cancer Cell Int. 15: 72. http:// dx.doi.org/10.1186/s12935-015-0223-Z

Bao XB, Ma Z, Gu JB, Wang XQ, et al. (2015b). IL-8 -251T/A polymorphism is associated with susceptibility to acute pancreatitis. Genet. Mol. Res. 14: 1508-1514. http://dx.doi.org/10.4238/2015.February.20.6

Chi DZ, Chen J and Huang DP (2015). Influence of interleukin-1b and interleukin-6 gene polymorphisms on the development of acute pancreatitis. Genet. Mol. Res. 14: 975-980.http://dx.doi.org/10.4238/2015.February.3.5

Gao SJ, Zhang L, Lu W, Wang L, et al. (2015). Interleukin-18 genetic polymorphisms contribute differentially to the susceptibility to Crohn's disease. World J. Gastroenterol. 21: 8711-8722. http://dx.doi.org/10.3748/wjg.v21.i28.8711

Giedraitis V, He B, Huang WX and Hillert J (2001). Cloning and mutation analysis of the human IL-18 promoter: a possible role of polymorphisms in expression regulation. J. Neuroimmunol. 112: 146-152.http://dx.doi.org/10.1016/ $\underline{\mathrm{S} 0165-5728(00) 00407-0}$

Janiak A, Leśniowski B, Jasińska A, Pietruczuk M, et al. (2015). Interleukin 18 as an early marker or prognostic factor in acute pancreatitis. Prz. Gastroenterol. 10: 203-207.http://dx.doi.org/10.5114/pg.2015.50993

Jia HL, Sun PL and Lu CQ (2015). Investigation of the association between interleukin-10 polymorphisms and risk of acute pancreatitis in a Chinese population. Genet. Mol. Res. 14: 15876-15881. http://dx.doi.org/10.4238/2015. December.1.39

Kalina U, Ballas K, Koyama N, Kauschat D, et al. (2000). Genomic organization and regulation of the human interleukin-18 gene. Scand. J. Immunol. 52: 525-530.http://dx.doi.org/10.1046/j.1365-3083.2000.00836.x

Karra VK, Gumma PK, Chowdhury SJ, Ruttala R, et al. (2015). IL-18 polymorphisms in hepatitis B virus related liver disease. Cytokine 73: 277-282. http://dx.doi.org/10.1016/j.cyto.2015.02.015

Kumaravel A, Zelisko A, Schauer P, Lopez R, et al. (2014). Acute pancreatitis in patients after bariatric surgery: incidence, outcomes, and risk factors. Obes. Surg. 24: 2025-2030. http://dx.doi.org/10.1007/s11695-014-1337-4

Lankisch PG, Apte M and Banks PA (2015). Acute pancreatitis. Lancet 386: 85-96. http://dx.doi.org/10.1016/S01406736(14)60649-8

Li D, Li J, Wang L and Zhang Q (2015a). Association between $I L-1 b, I L-8$, and $I L-10$ polymorphisms and risk of acute pancreatitis. Genet. Mol. Res. 14: 6635-6641.http://dx.doi.org/10.4238/2015.June.18.6

Li X, Ren D, Li Y, Xu J, et al. (2015b). Increased cancer risk associated with the -607C/A polymorphism in interleukin-18 gene promoter: an updated meta-analysis including 12,502 subjects. J. BUON 20: 902-917.

Liu JM, Liu JN, Wei MT, He YZ, et al. (2013). Effect of $I L-18$ gene promoter polymorphisms on prostate cancer occurrence and prognosis in Han Chinese population. Genet. Mol. Res. 12: 820-829. http://dx.doi.org/10.4238/2013.March.15.2

Myung DS, Lee WS, Park YL, Kim N, et al. (2015). Association between interleukin-18 gene polymorphism and Helicobacter pylori infection in the Korean population. Sci. Rep. 5: 11535. http://dx.doi.org/10.1038/srep11535

Shi JH, Niu LD, Chen XY, Hou JY, et al. (2015). Investigation on the IL-18 -607A/C and -137C/G on the susceptibility of ischemic stroke. Pak. J. Med. Sci. 31: 198-202.

Yousaf M, McCallion K and Diamond T (2003). Management of severe acute pancreatitis. Br. J. Surg. 90: 407-420.http:// dx.doi.org/10.1002/bjs.4179

Yuhara H, Ogawa M, Kawaguchi Y, Igarashi M, et al. (2014). Smoking and risk for acute pancreatitis: a systematic review and meta-analysis. Pancreas 43: 1201-1207.http://dx.doi.org/10.1097/MPA.0000000000000176

Zhou C, Ouyang N, Li QH, Luo SX, et al. (2015). The -137G/C single nucleotide polymorphism in IL-18 gene promoter contributes to tuberculosis susceptibility in Chinese Han population. Infect. Genet. Evol. 36: 376-380. http://dx.doi. org/10.1016/j.meegid.2015.10.014

Genetics and Molecular Research 15 (3): gmr.15038394 